\title{
Breaking the Stereotype: Women in Indian Fiction in English
}

\author{
Dr. Manjit Kaur \\ Dept. of English Post graduate Govt: College for Girls Sec.42 Chandigarh (UT) India
}

\begin{abstract}
The present paper seeks to study the selective fictional works of the Indian writers in English with a purpose to map the gradual erosion of the stereotypes built around women characters in the literary scene keeping with the growing awareness of the issues concerning women and their cause. The objective is also to trace the seeds of feminist ideology even in those writers who marked the scene of Indian writing in its very initial stages starting from the pre independence times growing to full bloom in the much radical works of the current writers. My study focuses on the selective fiction of $R$. K. Narayan, Mulk Raj Anand, Kamala Markandya, Anita Desai, Shashi Deshpande, Nayantara Sehgal and Bharati Mukherjee as a sufficient ground for the above argument. The choice of works for the analysis follows a particular line of thought without the intention of sounding reductive by nature keeping in mind the marathon contribution of the literary figures under study
\end{abstract}

Keywords: Culture, English, Fiction, Stereotypes, Women

\section{Introduction}

Language has a remarkable capacity to change or chain persons. Literature uses language as its medium to depict reality after passing it through the crucible of human imagination and vision. Language carries with it the stereotypes and values of a culture and the child while learning the language adopts these images and values naturally as he or she grows up. As NgugiwaThiong'O, a Kenyan writer states, "Language carries culture and culture carries particularly through orature and literature the entire body of values by which we come to perceive ourselves and others."[1]

Right since the formation of human society, language has been shaped and ordered as per the male ideology, the condition reflecting the patriarchal set up when the social structure rested strictly and quintessentially on the division of labour and a clear cut separation of the public and private spheres between men and women. This order has continued many centuries later even till today despite the rationalisation and the awareness brought about through the advancement of science and technology. Unfortunately, the healthy and requisite division of labour in the initial stages of human history takes the unjust and ugly form of proving the instrument of constraint and control on women exercised by men, who occupy a relatively advantageous position in the economic, political and social fields of society.

In a patriarchal society, hierarchies and polarisation in the men and women's relationship occur due to the stereotypes or the fixed viewpoints by which they seek to understand themselves as well as others. Having an upper hand and being positioned in the centre of social organisations, male allocates marginal space to the female. Human tendency to rule and control and think in terms of binary parameters of superior/inferior, culture /nature, normal/abnormal etc. attributes the less privileged characteristics to women who exist on the peripheral space of society. Stereotypes, "largely the reflection of culture" than being empirical by nature, take the form of knowledge in Foucault's terms.[2] These are the manifestations of the prejudiced attitudes of people promoting negative evaluation of the other sex. These notions perpetuate in society through institutions such as family, education, and media and become integral part of the process of socialisation of the beings resulting in women becoming both the victims of the oppression strategy as well as the perpetrators of their own subjugation.

Society lays down the patterns of life for a woman much before she takes birth by conceiving fixed identities for her. It confines her existence through binary divisions between the general conception of men and women defining her as feminine as opposite to the masculine, the characteristics marked in the formation of gender by society. Further, the association of negativity with the attributes which fall into the kitty of female, such as passivity, infantilism, emotionalism and irrationality as opposed to adventure, decisiveness and rationality in male, considered positive virtues, do great harm to her self assessment and individual progress. Moreover, the private sphere assigned to woman in the patriarchal system limits her role as daughter sister, wife and mother and also facilitates the control of her body by the opposite sex.

Within women themselves, polarisation is established as a 'natural' order, through the creation of white and black images in the categories of wife or whore, ideal woman or sorceress and mother or temptress. In order to earn respect in society, it is essential for a woman to belong to the preferred category of wife or an ideal woman and be oriented towards being obedient, devoted, self sacrificing as the mythical figures of Sita, Savitri and Draupadi. It is a different matter now that we have learnt to look at the strong aspects of these characters in 
terms of the resistance posed by them to their domination - thanks to the radical thinkers who have pulled us out of the stereotyped nature of our perspectives and led us to the free and neutral evaluation of the social reality around us.

\section{Indian Fiction In English}

Indian Fiction in English traces its origin with the advent of English education and English language in the pre independence era. It is firmly rooted in Indian cultural background and specifics which make it essentially different from English literature per se. In the post colonial period with the rise of feminist consciousness in Indian society, there came a flurry of writers who concerned themselves with the issues relating to women quite passionately. Yet the undercurrent of such themes and concerns were nevertheless present in the works of writers who began writing before independence such as R.K.Narayan, Mulk Raj Anand, and later Kamala Markandya and Anita Desai before culminating in the more obvious and even polemical writings as by Shashi Deshpande, Nyantara Sehgal and Bharati Mukherjee to name a few.

R. K. Narayan in his novel The Dark Room published in 1938, seeks to dismantle the stereotype of a happy house wife in his female protagonist Savitri. Quite sympathetically, Narayan portrays the sufferings of this South Indian middle class house wife who finds herself confined to the cramped environment of unhappy married life that imposes on her the demands of being obedient and submissive. Fed up with the whims and dominance of her unfaithful husband Ramani, she like a rebel, decides to leave the house and attempts to drown herself in the river Sarayu.Her suicide attempt fails as she is saved by a village blacksmith whose wife Pooni gives her shelter and helps her in getting the job of a temple caretaker for the local priest. Her failure to cope with the unfamiliar outer environment and life without her children whom she had left behind, lead Savitri to go back home resignedly and to sulk in the dark room of her house. Thus the plot takes a realistic turn set in the times when women's mental and physical dependence on men and their family made impossible for them to exit their difficult domestic circumstances and survive on their own. Notwithstanding his initial attempt, Narayan does succeed in making the house wife escape the futility of married life in his novel titled, The Guide published in 1958 incidentally two years after the Indian edition of The Dark Room. Set in an urban environment R. K. Narayan, here, deals with the life of an educated talented woman, Rosie who instead of wasting herself and sulking in the company of her indifferent husband Marco is able to seek identity and space for herself through her career in dancing and her romantic relationship with Raju.

The portrayal of the unhappy woman also occurs in Mulk Raj Anand's novel The Old Woman and the Cow or Gauri (1960) in which Gauri, a gentle and submissive woman, suffers first in her parental home as a daughter and later in her marital home till she meets a city doctor named Colonel Mahindra who empathises with her and becomes the mouthpiece for the angst and concern of the suffering women like her. From a timid and passive woman, Gauri turns into a self willed woman with clear awareness of her rights. She goes back to her husband only to be thrown out of the house as her husband doubts her chastity. What is more important is the way Anand makes her react to the situation. Instead of crying and pleading for forgiveness, Gauri tells her husband: "If I am a curse on you I will go away...And if you strike me again I will hit you back."[3]She even calls her husband a coward for acting like the mythical Ram who turned Sita out for the sake of the public opinion about the purity of a woman for living out of home in the company of another man. Thus Anand, by lending voice and language to the so called ideal woman of society succeeds in subverting another stereotype about women who are supposed to be silent sufferers.

Kamala Markandya in A Silence of Desire(1963) takes up the same issue but with a different focal point and ending. The novel deals with the agony of the female protagonist Sarojini who is seen coping with the male hegemony and patriarchal dominance in her domestic sphere. Her husband named Dandekar, a clerk in a Govt office has double sets of values for himself and for the women. For him, a wife is an asset and an inevitable prop in the household with no personal demands of her own. Seeing from Dandekar's view point, his marital life is an ideal one, a picture of harmony and peace in the company of a perfect woman as his wife who is acquiescent, uncomplaining and "an excellent cook,... who gives him pleasure after fifteen years of marriage..." doing most things placidly"...and from this calm proceeds the routine that meets"the neat and orderly needs of his nature."[4]Sarojini's secret visits to a swami, a faith healer due to a growth in her womb and also to break the monotony of her monotonous existence, punctures the conventional image of an Indian family.Dandekar suspects her of extra marital relation and as if to maintain his crumbling sense of masculinity, turns to prostitutes, ignores children and his work. Sarojini feels empowered through her interaction with the swami that uplifts her declining psyche restoring her faith and hope in life. Towards the end, Dandekar realises his mistake and learns to respect the true worth of his wife as a subject.

Woman as a subject with her own sets of emotions and desires at the conscious as well as the unconscious level still remained less talked till the handling of such issues by Anita Desai. In the same year as the publication of the already discussed novels in 1963, appeared Cry the Peacock that brought out, with great sympathy and empathy, the hitherto unexplored space of female psyche- her anger, maladjustments and 
psychotic disorder which earlier psychologists like Sigmund Freud had attributed to the biological determinism of women.

In the novel, Cry the Peacock, Maya loses her sanity at the detached and apathetic attitude of her husband. Driven to schizophrenia and the non acknowledgement of her unflinching and excessive love for life depicted through her intense emotional responses to the nature around her, she ends up killing her husband and taking away her own life.[5]In Indian society, where the matrimonial world is the ultimate world promising happiness and succour for a traditional woman who has interiorized this kind of concept since her childhood, an environment of alienation and loneliness, can prove to be disastrous not only for her but for other members as well.

The exploration of the dark and unknown recesses of the female self was a major breakthrough in the recognition of her subjectivity and individuality subverting the societal expectations and stereotypes established on her status of 'otherness'. In another novel titled Fire on the Mountain (1975) by Anita Desai which won her the Sahitya Academy Award, the author takes a peek into the psyche of her protagonist Nanda Kaul whose muteness at the face of her adulteress husband and the burden of looking after the great household teaming with children and grand children, finally goad her to search her own values away from the societal obligations as a wife, mother and a grandmother at the family house, Carginano, at Kasauli in Himachal Pradesh.

However, Nanda Kaul's isolation from the family does not make her apathetic towards the rest of the society which is evident from her re-establishing the link with Raka, her granddaughter, who like her, a recluse and freedom loving person, comes to live with her after the separation of her parents. Nanda is equally empathetic towards her old friend Ila Das, a social worker who often visits her and later on is raped and killed by the villagers for her intervention in a child marriage. The novel succeeds in smashing the stereotype of self sacrificing and self effacing woman, a mother and a wife in the character of Nanda Kaul in her refusal to carry with her the memories of "too many servants, too many visitors... and too many children going to different schools and colleges at different times and too many tutors"[6] in search of her real self to the place of her new abode. This real self of woman is not self centred and detached from society but the one that is well grounded in social reality and has learnt to care for itself.

Long preserved notions of mother- daughter closeness, glorification of woman's power of tolerance and her silence over private issues got dissipated in the fictional works which followed. Shashi Dehpande in her novel titled The Dark Holds No Terror makes her female protagonist Saru, a doctor by profession, share her mental agony for the sadistic sexual behaviour of her husband, with her father as she comes to meet him after the death of her mother. Unlike the conventionally held image of the mother - daughter closeness, Saru's mother had never loved her daughter and had never forgiven her for the childhood incident regarding the drowning of her younger brother in the village pond on the day she accompanied him. Saru comes back home to negotiate with the guilt, fear and emotional turmoil she has been undergoing as a daughter and the wife of a person called Manu, whose unexpected brutish behaviour during the nights that seems to be the projection of his insecurity as a male at the better social and professional placing of his wife, has left her confounded and traumatic. Saru's physical distance from her husband and sharing her grief with her father at her parental home ease down her mental and emotional anxiety, cleanse her vision and help her emerge stronger and more confident to face life back home.

The stereotype of the sexual frigidity in women has always been treated in ambiguous terms by the society. The control over one's sexual desires and the avoidance of any overt display had been the hallmark features of an Indian woman. Paeans have been written and sung in praise of women in literature and entertainment media to glorify such traits in them. However, ironically, sexual reticence on part of woman in relationship with her husband offers enough basis for the justification of the male deviation on the ground of wife's inability to please him. Indian literature in English has recognised such false and unjust images and sought to rectify them through the portrayal of real women with real physical desires, she has every right to express and fulfil like any other free individual.

Shashi Deshpande takes up this theme in her novel Roots and Shadows where Indu, as she comes to her share her claim over the family house after the death of her great aunt Akka, ponders over the futility of her married life with Jayant that has crushed her individuality. It is at this point that she learns to claim right over her body and her desires as she enters into a relationship with Naren, a distant relation. Even in the novel, That Long Silence, the questioning of the limiting effect on marriage on women is dealt with through the character of Jaya. The issue of rape within marriage shattering the old belief of the happy and peaceful marital existence of our older generation crops up in the novel The Binding Vine where Urmi, the female protagonist comes across the letters of her dead mother -in -law only to reveal the dreadful and repressive nature of her marriage.

The issues of silence about female sexuality and woman's right over her body are dealt emphatically by Nayantra Sehgal in many of her novels such as This time of Morning (1965), Storm in Chandigarh (1969) and The Day in the Shadow (1971) A situation in Delhi (2008) In our society, female body associated with the concept of honour, becomes an easy prop to exercise all kinds of control over her, be it the freedom to think, act, 
move and choose. In this context Jasbir Jain writes, "Men want to possess not only their present but also their past; thus feeding the ancient myths of the virgin bride and the virtuous wife"[7].Through the imposition of double standards of sexual morality, women are made to feel guilty for any deflection on their part in their pre and post marital lives. In Storm in Chandigarh, Inder punishes Saroj for having relation with a man before marriage by making her feel ashamed and an easy prey of his domination. The sanctimonious nature of marriage is challenged through the presentation of relationships which by the very nature of their emotional involvement do succeed in commenting on the denial of physical desires in women by society. In A Situation in Delhi, Devi a widow enters into fulfilling relationships with Michael and Usman Ali outside the formality of marriage. These fictional works, hence, do away with the categorisation of woman in the binary division between wife and whore or good or bad as defined by the conventional norms of society and present her as she exists in society in flesh and blood.

Women characters are depicted as shattering their fixed cultural and gender identities while stepping into the post modern diasporic world of fluid selves where they learn to cope with different cultures. Bharati Mukherjee's female protagonist Jasmine in the novel by the same name is a Panjabi girl who crosses all barriers-socio, cultural, religious and economic to assimilate with the foreign world and in the process of "rebirth" or the discovery of herself. From Jasmine Vijh in Jalandhar, she becomes Jazzy at Florida, reverts to her real name Jyoti in Flushing, is renamed Jase or Jazzy by her employer in New York, transforms into Jane Ripplemayer as Bud Ripplemayer's partner in Baden and finally becomes Jase again to Taylor and his daughter in her struggle to survive and provide dignity to herself. In this way, gender based division between the 'masculine' and 'feminine' is narrowed down by the daring, determined, extrovert and caring heroines like Jasmine.

\section{Conclusion}

Literature, as a part of culture, revises and rewrites values in consonance with the changing times of society. Unfortunately, despite all the benefits of constitutional rights in our country and scientific and ideological advancement at global and national levels, women still, in large number, occupy peripheral space in the socio cultural and political arena. The problem lies in the fixed mind set fuelled by the desire to control and age old beliefs and biases tearing the social fabric of our culture. Fiction, which is the most read and popular of all genres and Indian Fiction in English specifically for the growing love and usage of English, by shattering the stereotypes around women lend a great service in providing space for the real women to grow and utilize their full potentiality.

\section{References}

[1]. Ngugi waThiong' O, Decolonising the Mind: The Politics of Literature (Zimbabwe, Heinmann,1986) 16

[2]. David. J. Schneider, The Psychology Of Stereotyping,(London,The Guilford Press, 2005)

[3]. Mulk Raj Anand, The Old Woman and the Cow (Bombay,Kutub Popular,1960)283-284.

[4]. Nirod Banerjee, Kamala Markandya: Critical Study (Allahabad, Kitab Mahal, 1977) vii.

[5]. G.D Barche, Facets of Feminism in Indian English Fiction, R.K.Dhawan ed. Indian Women Novelists (New Delhi: Prestige, 1995)

[6]. Anita Desai, Fire on the Mountain (England, Penguin, 1997) 30.

[7]. Jasbir Jain, NayantaraSehgal in Pier Paolo Piciucco ed. A Companion to Indian Fiction in English (New Delhi, Atlantic, 2004$)$ 126. 